\title{
Overview of Glomerulus Filtration in Type 2 of Diabetes Mellitus at Sanjiwani Gianyar Hospital Year of 2018-2019
}

\author{
Putu Ayu Indah Saraswati \\ Physician, Sanjiwani Hospital, Gianyar, Bali, Indonesia \\ Corresponding Author email: indahsaraswati11@gmail.com \\ I Made Kasmadi Gunawan \\ Physician, Ganesha Hospital, Celuk, Sukawati, Bali, Indonesia \\ Dewa Gde Agung Budiyasa \\ Internist Specialist, Sanjiwani Hospital, Gianyar, Bali, Indonesia
}

\begin{abstract}
This study used a descriptive research design with a cross-sectional approach. This research was conducted at RSUD Sanjiwani Gianyar which was conducted from July to November 2019. The sample taken in this study must meet the inclusion criteria. This study uses secondary data in the form of patient medical records at Sanjiwani Gianyar Regional Hospital in 2018-2019. The research variables consisted of independent variables in the form of glomerular filtration rate and dependent variables in the form of type 2 diabetes mellitus patients. Data processing and analysis were carried out using computerized techniques with computer devices. Data analysis was carried out using univariate analysis used to analyze descriptively by calculating the frequency distribution of each research variable. The results of the research of 50 people with type 2 diabetes mellitus, the majority of respondents of LFG grade were grade 3 with a total of 18 people (36.0\%) and grade 1 as many as 15 people (30.0\%), while the lowest was grade 4 with a total of 2 (4.0\%) and grade 5 as many as 3 people (6.0\%).

Keywords---diabetes mellitus, glomerular filtration rate, glomerulus filtration.
\end{abstract}

\section{Introduction}

Diabetes mellitus (DM) is a group of metabolic diseases with hyperglycemia characteristics that occur due to abnormalities in insulin secretion, insulin action, or both (PERKENI, 2015). WHO predicts an increase in the number of people with diabetes in Indonesia from 8.4 million in 2000 to around 21.3 million in 2030 . DM has become one of the most common causes of chronic kidney disease. Kidney disorders resulting from diabetes mellitus are then known as Diabetic Kidney Disease (DKD) or Diabetic Nephropathy (ND) which is a chronic microvascular complication of renal capillary blood vessels in diabetes mellitus sufferers. Diabetic nephropathy ranks third (16.1\%) after chronic glomerulonephritis $(30.1 \%)$ and chronic pyelonephritis $(18.51 \%)$, as the most frequent causes of terminal renal failure requiring dialysis. Diabetic nephropathy ranks third $(16.1 \%)$ after chronic glomerulonephritis $(30.1 \%)$ and chronic pyelonephritis $(18.51 \%)$, as the most frequent causes of terminal renal failure requiring dialysis. (Unger \& Foster, 1998 \& Waspadji, 1996).

The kidneys cannot withstand hyperglycemia conditions, because the threshold for blood glucose is $180 \mathrm{mg} \%$ in the body so that if hyperglycemia occurs, the kidneys cannot filter and absorb a certain amount of glucose in the blood. Glomerular Filtration Rate (GFR) is widely used as an index of kidney function that can be measured indirectly by calculating renal clearance (Coll et al., 2000; Price \& Finney, 2000). Diabetic nephropathy is currently the leading cause of chronic kidney disease in the United States and other western countries. Diabetic nephropathy is also one of the most significant long-term complications in terms of morbidity and mortality for patients with DM. Given the large contribution of DM to chronic renal failure, leading to death in developed countries including 
Indonesia, it is important to identify patients who are at risk of developing Diabetic Nephropathy and End Stage of Renal Disease (ESRD) (Batuman, 2011).

The development of Diabetic Nephropathy usually focuses on 3 parameters: changes in albuminuria, changes in creatinine level or glomerular filtration rate, and death due to kidney disease and/or development of ESRD (MacIsaac et al., 2014). Glomerulus in patients with type 2 diabetes so that later they can intervene as early as possible so that disease progression can be controlled, and reduce the mortality rate due to chronic complications of DM.

\section{Methods}

This study used a descriptive research design with a cross-sectional approach. This research was conducted at RSUD Sanjiwani Gianyar which was conducted from July to November 2019. The sample taken in this study must meet the inclusion criteria. This study uses secondary data in the form of patient medical records at Sanjiwani Gianyar Regional Hospital in 2018-2019. The research variables consisted of independent variables in the form of glomerular filtration rate and dependent variables in the form of type 2 diabetes mellitus patients (Ozdemir et al., 2003; Rajput et al., 2012; Mustika et al., 2017). Data processing and analysis were carried out using computerized techniques with computer devices.

\section{Results}

The subjects in this study were 50 medical records of type 2 DM patients at Sanjiwani Gianyar Hospital in 20182019. The research was conducted from July to November 2019.

Table 1

Characteristics of Research Samples $(n=50)$

\begin{tabular}{|c|c|c|c|}
\hline \multirow{3}{*}{ GENDER } & Male & 21 & $42.0 \%$ \\
\hline & Female & 29 & $58.0 \%$ \\
\hline & GRADE 1 & 15 & $30.0 \%$ \\
\hline \multirow{5}{*}{$\begin{array}{l}\text { GFR } \\
\text { CLASSIFICATION }\end{array}$} & GRADE 2 & 12 & $24.0 \%$ \\
\hline & GRADE 3 & 18 & $36.0 \%$ \\
\hline & GRADE 4 & 2 & $4.0 \%$ \\
\hline & GRADE 5 & 3 & $6.0 \%$ \\
\hline & UNDERWEIGHT & 1 & $2.0 \%$ \\
\hline \multirow{5}{*}{$\begin{array}{l}\text { BMI } \\
\text { CLASSIFICATION }\end{array}$} & NORMAL & 10 & $20.0 \%$ \\
\hline & OVERWEIGHT & 14 & $28.0 \%$ \\
\hline & OBESITAS 1 & 21 & $42.0 \%$ \\
\hline & OBESITAS 2 & 4 & $8.0 \%$ \\
\hline & NORMAL & 24 & $48.0 \%$ \\
\hline GRADE OF & PRE HIPERTENSION & 6 & $12.0 \%$ \\
\hline \multirow[t]{2}{*}{ HYPERTENSION } & HIPERTENSION 1 & 8 & $16.0 \%$ \\
\hline & HIPERTENSION 2 & 12 & $24.0 \%$ \\
\hline
\end{tabular}

Based on the results of descriptive statistics on the research data, it was found that male respondents were 21 people $(42.0 \%)$ and female respondents were 29 people (58.0\%). The majority of respondents' LFG grade was grade 3 with 18 people $(36.0 \%)$ and grade 1 as many as 15 people (30.0\%), while the lowest grade was grade 4 with 2 people $(4.0 \%)$ and grade 5 as many as 3 people $(6.0 \%)$. For the clubbing index criteria obtained after being categorized in the WHO criteria for the Asian category, the tendency is more towards obesity category 1 as many as 21 people $(42.0 \%)$, after that overweight is 14 people $(28.0 \%)$, the normal criteria are 10 people $(20.0 \%)$, obesity 2 was 4 $(8.0 \%)$, and underweight was 1 person $(2.0 \%)$. Based on the criteria for blood pressure, it was found that the majority of respondents experienced normal blood pressure as many as 24 people $(48.0 \%)$, after that there were 12 people (24.0\%) who had grade 2 hypertension, grade 1 hypertension as many as 8 people $(16.0 \%)$ and prehypertension as many as 6 people $(12.0 \%)$. 
Table 2

Characteristics of Research Samples $(n=50)$

\begin{tabular}{lllll}
\hline & $\mathrm{N}$ & Minimum & Maximum & Mean \\
\hline AGE & 50 & 35 & 83 & 59.02 \\
GDP & 50 & 83 & 347 & 192.18 \\
G2PP & 50 & 89 & 444 & 199.18 \\
SYSTEM & 50 & 100 & 160 & 127.60 \\
DIASTOL & 50 & 70 & 120 & 86.60 \\
HB & 50 & 8.5 & 16.8 & 11.652 \\
CHOLESTEROL & 50 & 114 & 298 & 192.18 \\
UREUM & 50 & 15 & 89 & 49.08 \\
CREATININE & 50 & 0.40 & 6.30 & 1.248 \\
BMI & 50 & 17.97 & 31.25 & 24.92 \\
GDA & 50 & 29 & 580 & 223.82 \\
SGPT & 50 & 8 & 60 & 20.06 \\
SGPT & 50 & 8 & 33 & 18.60 \\
DM EXPERIENCED & 50 & 1 & 6 & 3.48 \\
GFR & 50 & 11.25 & 181.44 & 74.34 \\
Valid N (list wise) & 50 & & & \\
\hline
\end{tabular}

In table 2, it is found that the mean age of the respondents is $59.02 \%$, the mean length of time for respondents suffering from diabetes is $3.48 \%$ and the average LFG of respondents is $74.34 \%$.

Table 3

Overview of Glomerular Filtration Rate in Type 2 DM Patients Based on DM Experienced

\begin{tabular}{|c|c|c|c|c|c|c|c|c|}
\hline \multicolumn{9}{|c|}{$\begin{array}{l}\text { DURATION CATEGORY * CLASSIFICATION LFG Cross tabulation } \\
\text { LFG CLASSIFICATION }\end{array}$} \\
\hline & & & $\begin{array}{l}\text { GRAD } \\
\text { E } 1\end{array}$ & $\begin{array}{l}\text { GRADE } \\
2 \\
\end{array}$ & $\begin{array}{l}\text { GRADE } \\
3 \\
\end{array}$ & $\begin{array}{l}\text { GRADE } \\
4 \\
\end{array}$ & $\begin{array}{l}\text { GRAD } \\
\text { E } 5\end{array}$ & Total \\
\hline \multirow{6}{*}{$\begin{array}{l}\text { DURATION } \\
\text { CATEGORY }\end{array}$} & & Count & 5 & 3 & 3 & 1 & 1 & 13 \\
\hline & years & $\begin{array}{l}\% \text { within LFG } \\
\text { CLASSIFICATION }\end{array}$ & $33.3 \%$ & $25.0 \%$ & $16.7 \%$ & $50.0 \%$ & $33.3 \%$ & $26.0 \%$ \\
\hline & & Count & 4 & 5 & 11 & 1 & 2 & 23 \\
\hline & $\begin{array}{l}3-4 \\
\text { years }\end{array}$ & $\begin{array}{l}\% \text { within } \mathrm{LFG} \\
\text { CLASSIFICATION }\end{array}$ & $26.7 \%$ & $41.7 \%$ & $61.1 \%$ & $50.0 \%$ & $66.7 \%$ & $46.0 \%$ \\
\hline & & Count & 6 & 4 & 4 & 0 & 0 & 14 \\
\hline & $\begin{array}{l}\geq 5 \\
\text { years }\end{array}$ & $\begin{array}{l}\% \text { within LFG } \\
\text { CLASSIFICATION }\end{array}$ & $40.0 \%$ & $33.3 \%$ & $22.2 \%$ & $0.0 \%$ & $0.0 \%$ & $28.0 \%$ \\
\hline \multirow[b]{2}{*}{ Total } & & Count & 15 & 12 & 18 & 2 & 3 & 50 \\
\hline & & $\begin{array}{l}\% \text { within LFG } \\
\text { CLASSIFICATION }\end{array}$ & $100.0 \%$ & $100.0 \%$ & $100.0 \%$ & $100.0 \%$ & $100.0 \%$ & $100.0 \%$ \\
\hline
\end{tabular}

Table 3 shows that patients with type 2 diabetes who suffered from diabetes for 3-4 years experienced $66.7 \%$ grade 5 LFG. Then patients with type 2 diabetes who suffered from diabetes for 3-4 years experienced LFG grade 3 as much as $61.1 \%$. Furthermore, patients with type 2 diabetes who suffered from diabetes for 3-4 years experienced $50 \%$ grade 4 LFG. The same presentation was also found in patients with type 2 diabetes who had suffered from 1-2 years of experience with grade 4 GFR by $50 \%$ The same presentation was also found in patients with type 2 diabetes who had suffered from 1-2 years of experience with LFG grade 4 by $50 \%$. In patients with type 2 diabetes who suffered from type 2 diabetes for 1-2 years, the presentation experienced 50\% grade 1 and grade 5 GFR. Then, patients with type 2 diabetes who suffered from diabetes for 3-4 years experienced LFG grade 2 as much as $41.7 \%$. The percentage of patients with type 2 diabetes who suffered from type 2 diabetes for $\geq 5$ years experienced LFG grade 1 
as much as $40 \%$. In patients with type 2 diabetes who suffered from type 2 diabetes for $\geq 5$ years experienced LFG grade 2 as much as $33.3 \%$. Patients with type 2 diabetes who had suffered from diabetes for 3-4 years experienced LFG grade 1 with a presentation of $26.7 \%$. Furthermore, patients with type 2 diabetes who suffered from diabetes for 1-2 years experienced LFG grade 2 as much as $25 \%$. Patients with type 2 diabetes who suffered from diabetes for $\geq 5$ years experienced LFG grade 3 with a presentation of $22.2 \%$.

Table 4

Overview of Creatinine Value in Type 2 DM Patients Based on Glomerular Filtration Rate

\begin{tabular}{|c|c|c|c|c|c|c|c|c|}
\hline \multicolumn{9}{|c|}{ CREATININE CATEGORY * LFG CLASSIFICATION Cross-tabulation } \\
\hline & & & \multicolumn{5}{|c|}{ LFG CLASSIFICATION } & \multirow[b]{2}{*}{ TOTAL } \\
\hline & & & $\begin{array}{c}\text { GRADE } \\
1\end{array}$ & $\begin{array}{c}\text { GRADE } \\
1\end{array}$ & $\begin{array}{c}\text { GRADE } \\
1\end{array}$ & $\begin{array}{c}\text { GRADE } \\
1\end{array}$ & $\begin{array}{c}\text { GRADE } \\
1\end{array}$ & \\
\hline \multirow{9}{*}{$\begin{array}{l}\text { CREATININE } \\
\text { CATEGORY }\end{array}$} & & Count & 7 & 0 & 0 & 0 & 0 & 7 \\
\hline & Low & \% within LFG & & & & & & \\
\hline & & CLASSIFICATION & $46.7 \%$ & $0.0 \%$ & $0.0 \%$ & $0.0 \%$ & $0.0 \%$ & $14.0 \%$ \\
\hline & & Count & 8 & 12 & 10 & 0 & 0 & 30 \\
\hline & Normal & $\%$ within LFG & & & & & & \\
\hline & & CLASSIFICATION & $53.3 \%$ & $100.0 \%$ & $55.6 \%$ & $0.0 \%$ & $0.0 \%$ & $60.0 \%$ \\
\hline & Hioh & $\begin{array}{l}\text { Count } \\
\text { f }\end{array}$ & 0 & 0 & 8 & 2 & 3 & 13 \\
\hline & & CLASSIFICATION & $0.0 \%$ & $0.0 \%$ & $44.4 \%$ & $100.0 \%$ & $100.0 \%$ & $26.0 \%$ \\
\hline & & Count & 15 & 12 & 18 & 2 & 3 & 50 \\
\hline \multirow[t]{2}{*}{ Total } & & $\%$ within LFG & & & & & & \\
\hline & & CLASSIFICATION & $100.0 \%$ & $100.0 \%$ & $100.0 \%$ & $100.0 \%$ & $100.0 \%$ & $100.0 \%$ \\
\hline
\end{tabular}

Table 4 shows that in patients with type 2 diabetes who experienced LFG grade 5 with a high serum creatinine value of $100 \%$. Then in patients with type 2 diabetes who experience LFG grade 4 with high serum keratin values as much as $100 \%$. Patients with type 2 diabetes who experience grade 2 LFG have a normal serum creatinine of $100 \%$. Furthermore, patients with type 2 diabetes who experience LFG grade 3 have a normal serum creatinine of 55.6\%. The percentage of patients with type 2 diabetes who experienced 1st-grade GFR had a normal serum creatinine value of $53.3 \%$. Patients with type 2 diabetes who experience grade 1 GFR have a low serum creatinine value of $46.7 \%$. Furthermore, patients with type 2 diabetes who experienced LFG grade 3 had a high serum creatinine value with a presentation of $44.4 \%$.

\section{Discussion}

Based on the inclusion and exclusion criteria, 50 people met the research criteria. Based on the results of descriptive statistics in the research data, it was found that 21 respondents were male $(42.0 \%)$ and 29 female respondents $(58.0 \%)$, indicating that women have a greater risk of suffering from diabetes than men. The prevalence of type 2 diabetes is also characterized by gender differences. Overall, the global prevalence of diabetes is higher in men, but there are more women with diabetes than men. The sex difference behind diabetes prevalence depends on the stage of reproductive life (Wild et al., 2004). This means that there are more women with diabetes after menopause and at older ages. The EPIC-InterAct study, a prospective study of more than 10 years, concluded that early menopause (before age 40) was associated with a greater risk of developing type 2 diabetes than women who had menopause who occurred after age 50 years (Brand et al., 2013). Likewise, an observational study in More than 16,000 Chinese women reported that early menopause (before age 45) was associated with an increased risk of diabetes than menopause starting at 50 years old (Shen et al., 2017).

Most of the respondents' LFG grade was grade 3 with a total of 18 people (36.0\%), grade 2 was 12 people $(24.0 \%)$, grade 1 was 15 people $(30.0 \%)$, while the lowest was grade 4 with a total of 2 people $(4.0 \%)$ and grade 5 as many as 3 people $(6.0 \%)$. Based on a study by Dorte et al, it was found that the glomerular filtration rate was on a progressive decrease trajectory when it entered grade 3. In the study of Paula et al. In Brazil, using the results of a practical study to calculate LFG estimated by Modification of Diet in Renal Disease (MDRD) 36,3\% of patients 
were found to show a level below $60 \mathrm{~mL} /$ minute $/ 1.73 \mathrm{~m} 2$. This represents an estimated $50 \%$ reduction in normal kidney function (Fontela et al., 2014).

In the clubbing index criteria obtained after being categorized in the WHO criteria for the Asian category, the tendency is more towards obesity category 1 as many as 21 people $(42.0 \%)$, after that overweight is 14 people (28.0\%), normal criteria are 10 people $(20.0 \%)$, obesity 2 was 4 people $(8.0 \%)$, and underweight was 1 person (2.0\%). A higher BMI is a risk factor for End-Stage Renal Disease (ESRD). In a study conducted by Chi Yuan et al. In China in 2006, compared with people of normal weight (BMI, 18.5 to $24.9 \mathrm{~kg} / \mathrm{m} 2$ ), the risk factor for developing ESRD was 1.87 (95\% CI, 1, 64 to 2.14) in the category (BMI, 25.0 to $29.9 \mathrm{~kg} \mathrm{~m} 2$ ), 3.57 (CI, 3.05 to 4.18) for those with class I obesity (BMI, 30.0 to $34.9 \mathrm{~kg} / \mathrm{m} 2$ ). A higher baseline BMI remains an independent predictor for ESRD. (Chi-yuan Hsu et al., 2006).

Based on the criteria for blood pressure, it was found that the majority of respondents experienced normal blood pressure as many as 24 people (48.0\%), after that there were 12 people (24.0\%) who had grade 2 hypertension, grade 1 hypertension as many as 8 people $(16.0 \%)$ and prehypertension as many as 6 people $(12.0 \%)$. This is inversely proportional to a study conducted by Yukako et al which found that about $50 \%$ of diabetes patients suffer from hypertension, and about $20 \%$ of hypertensive patients suffer from diabetes mellitus. However, literature has proven that diabetes mellitus and hypertension can cause complications in the form of cardiovascular disease and kidney failure. In Japan, the Japan Diabetes Complications Study (JDCS) reports that the risk of progression to proteinuria is 2.55 (95\% CI: 0.98-6.33) times higher in diabetics with systolic blood pressure $\geqslant 140 \mathrm{~mm} \mathrm{Hg}$ compared with patients diabetes with systolic blood pressure $\leq 120 \mathrm{mmHg}$ (Tatsumi \& Ohkubo, 2017).

Table 3 shows that patients with type 2 diabetes who had suffered from diabetes for 3-4 years experienced $66.7 \%$ grade 5 LFG. This is different from research which states that kidney damage rarely occurs in the first 10 years of suffering from diabetes and will usually occur after 15-25 years of suffering from diabetes. Meanwhile, people who live with diabetes for more than 25 years have a risk of suffering from kidney failure as much as $79 \%$. However, in a study conducted by Amira et al. (2014), there was no relationship between the length of suffering from diabetes and GFR because glomerular filtration rate does not only depend on the length of diabetes but there are other factors that affect kidney function, such as hypertension (Amira et al., 2014).

Table 4 shows that patients with type 2 diabetes who experience LFG grade 5 with high serum creatinine values are $100 \%$. Patients with type 2 diabetes who experience grade 2 GFR have a normal serum creatinine of $100 \%$. In a previous study conducted by Naveen in 2010, a similar thing was found, namely that there was a significant increase in serum creatinine levels in uncontrolled type 2 diabetes mellitus patients. This occurs as an improvement to the hyperfiltration that occurs in early-stage DM patients. Furthermore, as the disease progresses, good glycemic control will provide protection against kidney disorders by improving the rate at which LFG decreases, and vice versa (Naveen et al., 2012).

\section{Conclusion}

The results of the research of 50 people with type 2 diabetes mellitus, the majority of respondents of LFG grade were grade 3 with a total of 18 people (36.0\%) and grade 1 as many as 15 people (30.0\%), while the lowest was grade 4 with a total of $2(4.0 \%)$ and grade 5 as many as 3 people $(6.0 \%)$.

\section{References}

Amira, N., Pandelaki, K., \& Palar, S. (2014). Hubungan Tekanan Darah dan Lama Menderita Diabetes Dengan Laju Filtrasi Glomerulus Pada Subjek Diabetes Melitus Tipe 2. e-CliniC, 2(1).

Batuman, V. (2011). Diabetic Nephropathy.[internet]: medscape reference; 2011 [updated 2011; cited 2011 Nov 20].

Brand, J. S., Van Der Schouw, Y. T., Onland-Moret, N. C., Sharp, S. J., Ong, K. K., Khaw, K. T., ... \& InterAct Consortium. (2013). Age at menopause, reproductive life span, and type 2 diabetes risk: results from the EPICInterAct study. Diabetes care, 36(4), 1012-1019.

Coll, E., Botey, A., Alvarez, L., Poch, E., Quintó, L., Saurina, A., ... \& Darnell, A. (2000). Serum cystatin C as a new marker for noninvasive estimation of glomerular filtration rate and as a marker for early renal impairment. American journal of kidney diseases, 36(1), 29-34. https://doi.org/10.1053/ajkd.2000.8237

Fontela, P. C., Winkelmann, E. R., Ott, J. N., \& Uggeri, D. P. (2014). Estimativa da taxa de filtração glomerular em pacientes com diabetes mellitus tipo 2. Revista da Associação Médica Brasileira, 60(6), 531-537. 
Hsu, C. Y., McCulloch, C. E., Iribarren, C., Darbinian, J., \& Go, A. S. (2006). Body mass index and risk for endstage renal disease. Annals of internal medicine, 144(1), 21-28.

MacIsaac, R. J., Ekinci, E. I., \& Jerums, G. (2014). Markers of and risk factors for the development and progression of diabetic kidney disease. American journal of kidney diseases,63(2), S39-S62. https://doi.org/10.1053/j.ajkd.2013.10.048

Mustika, I. W., Candra, I. W., \& SC, N. Y. (2017). The Relationship between the Level of Spiritual and Self-Esteem on Depression towards Patients with Diabetes Mellitus. International Research Journal of Engineering, IT and Scientific Research, 2(7), 125-133.

Naveen, P., Kannan, N., Vamseedhar Annam., Bhanu Prakash, G., Aravind Kumar, R. (2012). Evaluation of Glycated hemoglobin and Microalbuminuria as early risk markers of Nephropathy in Type 2 Diabetes Mellitus. Int J Biol Med Res. 2012; 3(2), 1724-1726

Ozdemir, M., Buyukbese, M. A., Cetinkaya, A., \& Ozdemir, G. (2003). Risk factors for ocular surface disorders in patients with diabetes mellitus. Diabetes research and clinical practice,59(3), 195-199. https://doi.org/10.1016/S0168-8227(02)00244-9

PERKENI. (2015). Konsensus Pengelolaan dan Pencegahan Diabetes Melitus tipe2 di Indonesia. Jakarta, p. 56-7.

Price, C. P., \& Finney, H. (2000). Developments in the assessment of glomerular filtration rate. Clinica chimica acta, 297(1-2), 55-66. https://doi.org/10.1016/S0009-8981(00)00233-3

Rajput, R., Rajput, M., \& Nanda, S. (2012). Utility of HbA1c for diagnosis of gestational diabetes mellitus. Diabetes research and clinical practice, 98(1), 104-107. https://doi.org/10.1016/j.diabres.2012.02.018

Shen, L., Song, L., Li, H., Liu, B., Zheng, X., Zhang, L., ... \& Wang, Y. (2017). Association between earlier age at natural menopause and risk of diabetes in middle-aged and older Chinese women: The Dongfeng-Tongji cohort study. Diabetes \& metabolism, 43(4), 345-350. https://doi.org/10.1016/j.diabet.2016.12.011

Tatsumi, Y., \& Ohkubo, T. (2017). Hypertension with diabetes mellitus: significance from an epidemiological perspective for Japanese. Hypertension Research, 40(9), 795-806.

Unger, R. H., \& Foster, D. W. (1998). Diabetes mellitus-complications of diabetes. Williams Textbook of Endocrinology. 9th ed. Philadelphia: WB Saunders, 1013-22.

Waspadji, S. (1996). Komplikasi Kronik Diabetes Melitus: Pengenalan dan Penanganannya. Dalam editing Noer, MS. Buku Ajar Ilmu Penyakit Dalam, Jilid I, Edisi Ketiga. Jakarta: Balai Penerbit FKUI, 590-596.

Wild, S., Roglic, G., Green, A., Sicree, R., \& King, H. (2004). Global prevalence of diabetes: estimates for the year 2000 and projections for 2030. Diabetes care, 27(5), 1047-1053. 